\title{
台形断面の波型中間材を有する積層パネルのたわみ挙動
}

\author{
後藤 明*1, 燈明 泰成 ${ }^{* 2}$
}

\section{Deflection behavior of sandwich panel with corrugated core of trapezoidal cross section}

\author{
Akira GOTO*1 and Hironori TOHMYOH ${ }^{* 2}$ \\ ${ }^{* 1}$ M\&M GOTO Professional Engineer Office \\ 1234-84 Sakanoi, Motegi-cho, Haga-gun, Tochigi 321-3544, Japan \\ ${ }^{* 2}$ Department of Finemechanics, Graduate School of Engineering, Tohoku University \\ 6-6-01 Aoba, Aramaki, Aoba-ku, Sendai 980-8579, Japan
}

Received: 27 September 2021; Revised: 15 November 2021; Accepted: 27 December 2021

\begin{abstract}
This paper reports the deflection behavior of the sandwich panel with corrugated core of trapezoidal cross section. The size of the top and bottom plates were $200 \mathrm{~mm}$ square, and the height of the sandwich panel was fixed at $13.6 \mathrm{~mm}$. The models for finite element method were created by taking into account the geometrical limitations of the corrugated core due to the space between both plates and the manufacturing condition. The four sides of the sandwich panel were rigidly fixed, and a uniformly distributed load was applied to the surface of the top plate. The deflection always became maximum at the center of the panel. The analysis was performed by changing the inclination angle of the trapezoidal patterns of the core. It was found that there is an inclination angle of the patterns at which the deflection of the sandwich panel becomes minimal. The deflection of the corrugated core itself increased with decrease in the inclination angle of the trapezoidal patterns. On the other hand, the shear stress developed in the plates and the core increased with decrease in the inclination angle, which had the effect of reducing the deflection of the sandwich panel. It was found that these synergistic effects cause the minimal inclination angle occur. Moreover, the anisotropy of deflection of the sandwich panel, which is the difference in the deflection depending on the selected two sides of the panel when the relative two sides are fixed and loaded, was investigated. It was found that the anisotropy of deflection also became smaller at the inclination angle of the trapezoidal patterns at which the deflection of the panel became minimal.
\end{abstract}

Keywords : Sandwich panel, Corrugated core, Trapezoidal patterns, Aluminu alloy, Deflection behavior, FEM, Shear stress

\section{1. 緒言}

自動車などの移動体における構成部材の軽量化は，所要エネルギーの削減，資源の節約，性能向上の観点から 重要な課題となっている．特に自動車においては年々厳しくなる世界的な燃費規制の動向や車両の衝突安全性強 化のニーズが背景にあり，自動車の運動性能向上のニーズと相まって車両軽量化技術の研究開発が必須の状況に ある. 構造部材の軽量化は，低比重材や高強度材への材料置換，あるいは材料は変えずにその使い方を工夫する 方法に大別され，両者は相互補完的な関係にある．前者ではアルミ系材料やハイテン鋼板などの適用が既に進ん でおり (Goto et al., 2011)，更なる高強度化や新しい高強度軽量材料の開発が活発に行なわれている。一方後者の 方法は，入手が容易で調達コストが低い材料を活用して軽量化できる利点がある．例えば中間材としてのハニカ ムコアを上下から平板でサンドイッチした積層パネル(野口, 1985; 小林他, 1994; Chen and Davalos, 2005; Wilbert et al., 2011) は比較的面積の大きな部材へも適用でき, 大きな軽量化効果を期待することができる. 近年では様々 な形状の中間材を用いた積層パネルの変形特性や破壊機構が実験と解析の両面から調査されている (Feng et al.,

No.21-00293 [DOI:10.1299/transjsme.21-00293], J-STAGE Advance Publication date : 13 January, 2022

*1 正員，M\&M 後藤技術士事務所（下321-3544 栃木県芳賀郡茂木町大字坂井 1234-84）

*2 正員, 東北大学大学院工学研究科ファインメカニクス専攻（†980-8579 宮城県仙台市青葉区荒巻字青葉 6-6-01）

E-mail of corresponding author: cappella@tk9.so-net.ne.jp 
2017; Wu et al., 2018; Zhang et al., 2020). 一例として, 波型中間材を有する積層パネルの等価平板モデルが提案さ れている (Xia et al., 2012; Cheon and Kim, 2015).

現状において，積層パネルの多くは機械的負荷が比較的軽い条件下で使われるケースが多い，八ニカムコアを 中間材として用いる場合には平板との接合部が線状となり，積層パネルの各層間の力の伝達や周辺の取付先への 力の伝達が不安定となり易いためと考えられる．機械的負荷を常態的に受ける部材への積層パネルの適用に際し てはパネルの剛性を更に高める必要がある，例えば，積層パネル上を人間が移動する場合では不安や恐怖を抱か ないようたわみ量を一定值以内にすることが求められる。また流体の圧力を受けながら流路を形成するような部 位に積層パネルが適用される場合にはパネルの変形が流れに大きく影響を及ぼさないよう，たわみ量の上限值が 設定されることも考えられる．これらの場合には積層パネルの強度以前に剛性が制約となる．

ところで台形断面の中間材は上下平板との接合部領域が確定的であるため, 力の伝達に重要な接合面積を安定 して確保することができる(高橋, 2011; 高橋他, 2013; Du et al., 2018).さらにプレス成形を前提とした場合には周 辺部材との締結に必要なフランジ部も比較的容易に成形し易く, 積層パネルの高剛性化を実現する中間材として 有望である. 具体的な例として, 福祉車両スロープ等への適用が検討されている(後藤, 西山, 2018a; 後藤, 西山, 2018b).

本研究では，台形断面の波型中間材を有する積層パネルのたわみ挙動を明らかにすることを目的とする．ここ に積層パネルの上下平板の大きさと平板間距離を固定とした際に中間材の台形模様が幾何学的な制約を受けるこ と，また中間材の台形断面が冷間プレスによって平板から成形されることを考慮して板厚を決定した解析モデル を設定し, 有限要素法 (FEM)による解析を実施した. 積層パネルの四辺を固定して上平板に一様分布荷重を負荷 した際，積層パネルのたわみは中央で最大となるが，この最大たわみが，ある中間材側壁傾斜角度で極小となる ことを示す．またその角度が発現した理由について考察する。

\section{2. 数値解析方法}

\section{$2 \cdot 1$ 積層パネルの概要}

対象とする積層パネルの概略図を図 1 に示寸. 台形断面の波型中間材を上下の正方形平板でサンドイッチした 積層構造である.中間材は上下の平坦部とその間の側壁傾斜部から成り, 平坦部と上下平板との間に幅 $L$ の接合 層を設けてある. ここで台形模様が繰り返される方向を「台形模様方向」と称する. 正方形平板の一辺の寸法を $W$, 上平板の表面と下平板の裏面との距離を $H$ と寸る. $H$ の内訳は, 上下平板の厚さ, 中間材高さ, および上下 平板と中間材との接合層の厚さである.

中間材の基礎となる台形模様の 1 サイクル分を図 2 に模式的に示寸. 模様は中央の一点鎖線に対して左右対称 である. また実線で示された左側 $1 / 2$ サイクルの部分は図中の点 A に対して点対称形となっている.ここで台形 模様の高さを $h$, 模様 1 サイクル分のピッチ長を $p$, 頂部又は谷部の平坦部の幅を接合層のそれと同じ $L$ とする. $\theta$ は傾斜面と水平面とのな寸角度 (中間材側壁傾斜角度)であり, 本研究で注目する重要な因子である. $\theta$ の下限值 $\left(\theta_{\min }\right)$ は $p$ および $h$ から幾何学的に決まる. また $\theta$ の上限值は成形体の取り出し作業上 $90^{\circ}$ 以下に限定される. 台 形模様のサイクル数を $n$ としたとき, $\theta_{\min }<\theta<90^{\circ}$ の範囲において式(1)～式(3)が幾何学的に成立する.

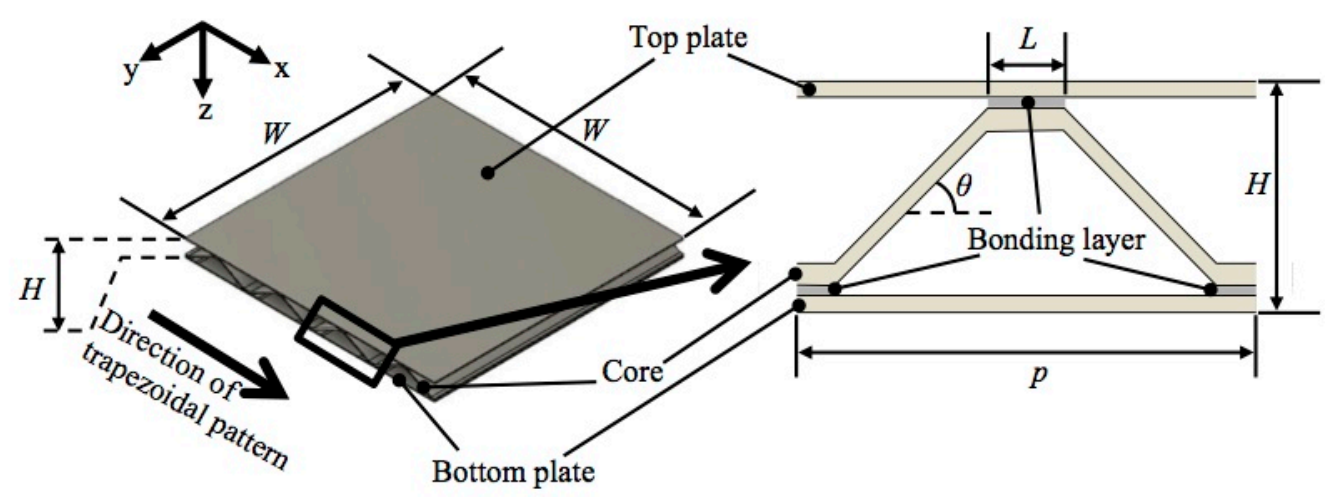

Fig. 1 Overview of the sandwich panel with corrugated core of trapezoidal cross section. 


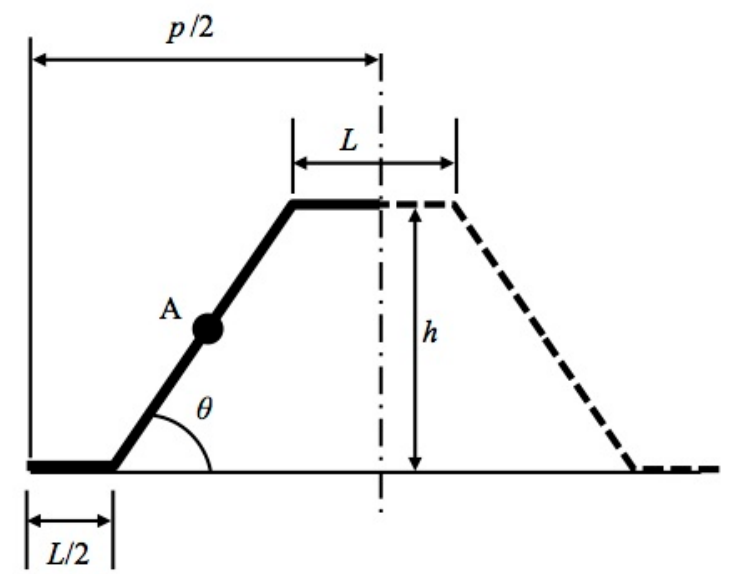

Fig. 2 Schematic diagram of trapezoidal pattern of the core.

$$
\begin{aligned}
& W=n p \\
& \frac{p}{2}=L+\frac{h}{\tan \theta} \\
& \tan \theta_{\min }=\frac{2 h}{p}
\end{aligned}
$$

積層パネルを周辺骨格部に取り付けて使用することを考えると，Wは周辺の骨格部材との締結上の整合 性の結果として二次的に決まることが一般的である.また $n$ の值は整数であるため, $p$ と $h$ 自由に設定で きない. そこで $p$ と $h$ を周辺との整合により決定する固定值とすると, 式(2)より $L$ は $\theta$ の増加に伴い増加 する.すなわち $\theta$ が決まれば接合領域が確定することとなる. 本研究で用いた台形模様の寸法範囲を表 1 に 示す.

Table 1 Geometry of trapezoidal patterns of the corrugated core

\begin{tabular}{c|c|c|c}
\hline \hline$h(\mathrm{~mm})$ & $p(\mathrm{~mm})$ & $\theta\left(^{\circ}\right)$ & $L(\mathrm{~mm})$ \\
\hline 10 & 50 & $23 \sim 70$ & $1.4 \sim 21.4$ \\
\hline
\end{tabular}

\section{2 -2 冷間プレス加エを考慮した中間材のモデル化}

図 3 に中間材 $1 / 2$ サイクル分の断面を模式的に示す. 板厚中央の二点鎖線は台形模様を示している. 中間材が 冷間プレス加工によって平板から成形される際, 平板全体の中のある部分が塑性変形して台形断面形状が形成さ れる. この時, 複数の台形模様が繰り返されるような断面であるので, 周辺領域からの材料流入はほとんど期待 できず，台形模様の存在する領域内の材料の塑性変形により成形が進行すると考えられる.そこで本研究では, 頂部が図 3 の破線で囲まれた領域 A の材料により, 傾斜部が破線で囲まれた領域 B の材料により形成されると仮 定した. ここで台形模様の側壁の板厚を $t$, 頂部や谷部の平坦部の板厚を $t_{0}$ すると, $t$ は次式で与えられる.

$$
t=t_{0} \cos \theta
$$

式(4)より， $\theta$ が決まれば $t$ が決定し， $t$ は $\theta$ の増加に伴い減少する.

\section{$2 \cdot 3$ 有限要素法解析}

本研究では，台形断面の波型中間材を用いた積層パネルに着目して，中間材側壁傾斜角度 $(\theta)$ がたわみに及ぼ す影響を調査するが，傾斜角度毎の金型を複数準備することは現実的でない．また相対する二辺固定の場合の一 方向の曲げ問題では弾性力学による解法も活用できるが (Du et al., 2018), 本研究で取り扱う四辺固定の場合は単 
純な平板の場合でも複級数計算が必要となり (土木学会構造工学委員会, 2003), 容易ではない. そこで本研究では, 上述の中間材の幾何学的制約を考慮した解析モデルを用い，有限要素法による解析を行った.

解析には統合ソフトウエア FUSION 360 (Autodesk, Inc., California, USA) を用いた. ソルバーには Inventor Nastran が採用されている．積層パネルモデルは $1 / 4$ 対称であるのでこの部分を解析対象とした (図 4). 要素分割には四 面体二次要素を用い，パネルが周辺骨格部に締結されて使用されることを前提として四辺固定とした. また力学 的負荷条件として, 人間一人の体重 $(67 \mathrm{~kg})$ が積層パネル表面に均等に負荷されることを想定した. 上下の正方形

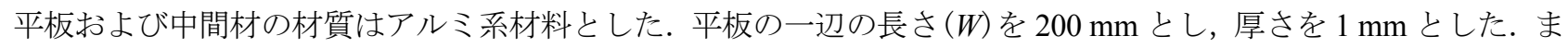
た接合層はエポキシ系樹脂を想定し, 接合層の厚さは $0.3 \mathrm{~mm}$ とした. 解析に用いたアルミ系材料とエポキシ系 樹脂のヤング率，ポアソン比を表 2 に示寸．また積層パネルの重量の算出のために用いた比重も表 2 に示す. な お予め要素分割を変更した解析モデルを用いて解の収束性を確認すると共に，単一板材に対する解析のたわみ量 が理論值と一致することを確認している.

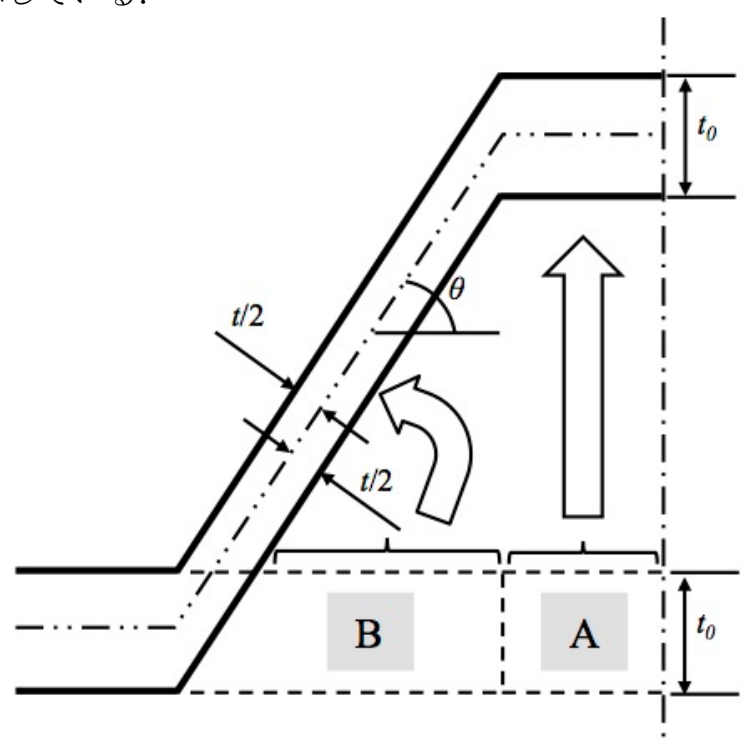

Fig. 3 Cross section of the trapezoidal pattern of the core fabricated by cold press.

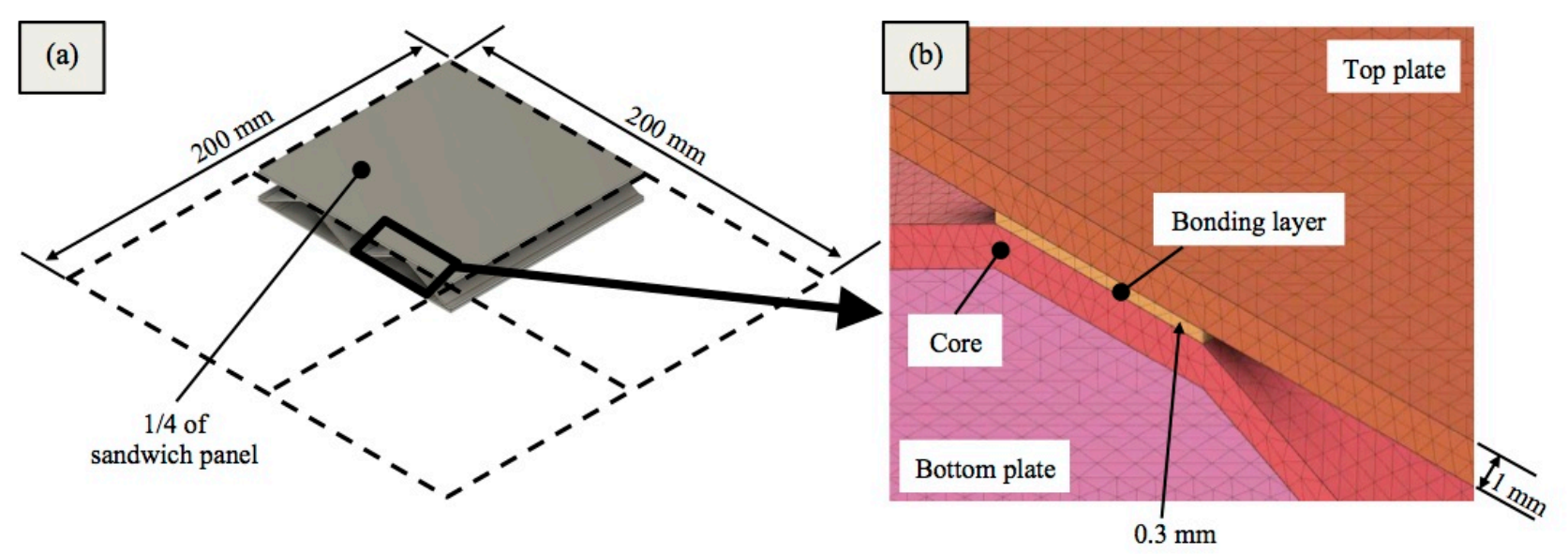

Fig. 4 Example of FEM model. (b) Details around the bonding layer.

Table 2 Physical properties of Al alloy and epoxy resin

\begin{tabular}{l|c|c|c}
\hline \hline Materials & $\begin{array}{c}\text { Young's modulus } \\
(\mathrm{GPa})\end{array}$ & Poisson's ratio & Specific gravity \\
\hline Al alloy & 68.6 & 0.3 & 2.7 \\
\hline Epoxy resin & 2.7 & 0.3 & 1.2 \\
\hline
\end{tabular}




\section{3. 解析結果}

\section{3 - 1 等分布荷重を受ける四辺固定積層パネルの変形の様子}

図 5 (a)に, 四辺固定の積層パネルの上平板表面に均等分布荷重 $\left(16.4 \mathrm{kN} / \mathrm{m}^{2}\right)$ を負荷した際にパネルが変形する 様子を示す. ここに台形模様方向に $x$ 軸, これと直交する平板の辺方向に $y$ 軸とする座標系を定め, 原点を二辺 の頂点に定める. 図は $\theta=27^{\circ}$ の場合の一例であり，上下平板が $z$ 方向に変形している様子がわかる.

図 $5(\mathrm{~b})$ に $y=100 \mathrm{~mm}$ における，上下平板の $z$ 方向変位の $x$ 方向分布を示す. 均等分布荷重を直接受ける上平板 では，中間材の台形模様の凹凸に対応した周期的な凹み変形が見られる。この部分ではパネル全体としてのたわ みと，台形模様の凹部に沿った局所的なたわみが生じているものと考えられる．一方，下平板では，上平板で見 られた周期的な凹み変形はほとんじ生じていない. 図 5 (c) に $x=100 \mathrm{~mm}$ における, 上下平板の $z$ 方向変位の $y$ 方 向分布を示す. 台形模様方向と直角方向の分布であるため，上平板においても中間材の台形模様に沿った周期的 な変形は認められない. また $y=40 \mathrm{~mm}$ 程度以降においてたわみ量が最大值に収束していくことがわかる. 下平 板では主にパネル全体としてのたわみが大きく反映されると考えられる. そこで以下の議論では，荷重を直接受 けない下平板の中央 $[(x, y)=(100 \mathrm{~mm}, 100 \mathrm{~mm})]$ における $z$ 方向変位をたわみ量の指標とする.

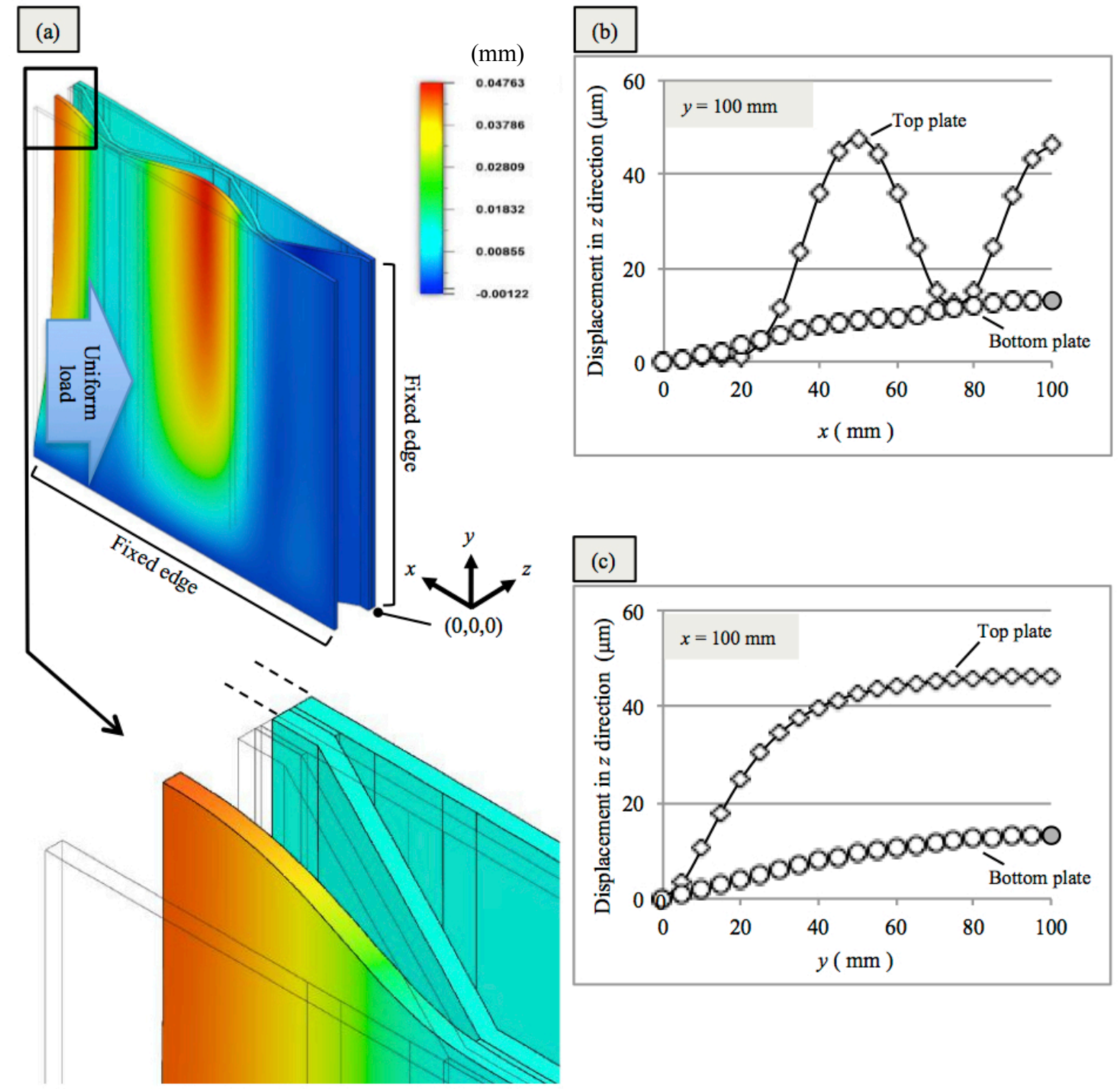

Fig. 5 Deformation of the sandwich panel. (a) Contour plot of the deflection. (b) Distribution of deflection in the $x$ direction at $y=100 \mathrm{~mm}$. (c) Distribution of deflection in the $y$ direction at $x=100 \mathrm{~mm}$. 

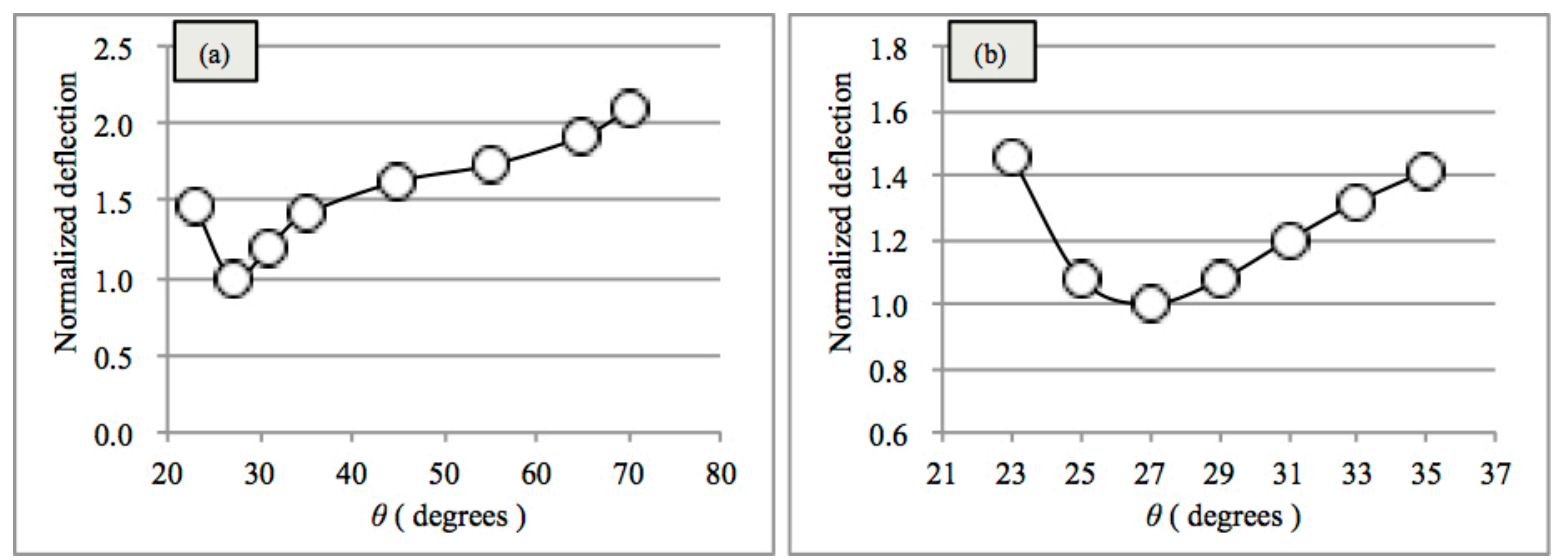

Fig. 6 Relationship between the normalized deflection and $\theta$. (b) is the magnified view of (a).

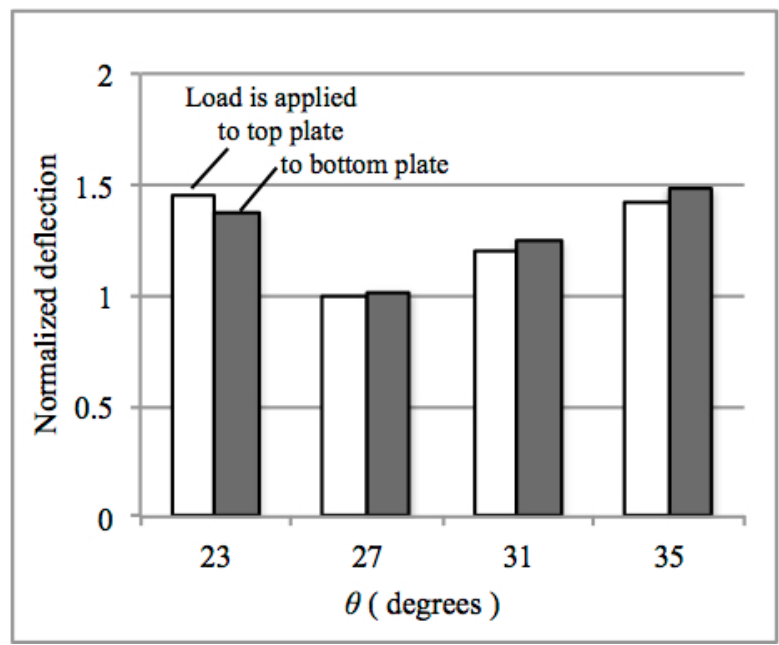

Fig. 7 Comparisons of the normalized deflection between the different loading directions at various values of $\theta$.

\section{$3 \cdot 2$ 中間材側壁傾斜角度と積層パネルのたわみ量との関係}

図 6 に $(x, y)=(100 \mathrm{~mm}, 100 \mathrm{~mm})$ におけるたわみ量と中間材側壁傾斜角度 $\theta$ との関係を示寸.ここでたわみ量は $\theta=27^{\circ}$ のたわみ量 $(13.2 \mu \mathrm{m})$ で正規化した. 図 $6(\mathrm{a})$ は $\theta=23^{\circ} \sim 70^{\circ}$ の広い角度範囲で解析した結果である. 積層パ ネルのたわみ量が $\theta$ にって大きく変化し, 低角度側で凹型となり, 高角度側で一様に増加することがわかる. 図 6(b) に低角度 $\theta=23^{\circ} \sim 35^{\circ}$ の範囲をより詳細に解析した結果を示寸. $\theta=27^{\circ}$ 付近でたわみ量が極小となること がわかる．この角度範囲でのたわみ量を三次関数近似して得た導関数から算出した，たわみ量が極小となる $\theta$ の 值 $\left(\theta_{\mathrm{md}}\right)$ は $27.1^{\circ}$ であった. 比重より算出した本積層パネルの重量は $0.327 \mathrm{~kg}$ であった. $\theta_{\mathrm{md}}$ におけるたわみ量をア

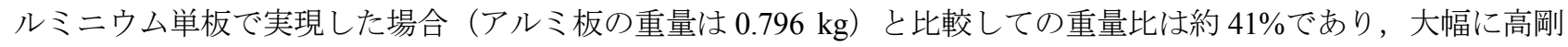
性化できていることがわかった。

\section{$3 \cdot 3$ たわみ量が最小となる角度付近でのたわみ特性}

たわみ量が最小となる中間材側壁傾斜角度 $\left(\theta_{\mathrm{md}}\right)$ 付近でのたわみ特性について解析した. 中間材の台形模様は上 下対称ではないため, 負荷方向が積層パネルのたわみ量に影響を及ぼす可能性がある. 図 7 は負荷方向を変化さ せた場合のたわみ量を示す．図中の白抜きの棒グラフは上平板に負荷をかけた時のパネルたわみ量を示し[図 6(b) と同じ], 灰色の棒グラフは下平板に負荷をかけた時のパネルたわみ量を示寸. 負荷の方向が逆転した場合で も $\theta_{\mathrm{md}}$ 付近でたわみ量が極小となり，またたわみ量の值も同程度であることがわかる.

次にたわみ異方性について解析した，様々な波型中間材を有する積層パネルにおいては，たわみ量の異方性に も注目すべきである.ここでたわみ量の異方性とは, 積層パネルの相対する 2 辺（2.1 節で定義した，図 1 に示す 台形模様方向と平行な 2 辺, または垂直な 2 辺）を固定して負荷した際の，選択する 2 辺の違いによるたわみ量 
の差異であり，小さいほうが望ましい。これまでに台形断面の波型中間材を有する積層パネルの三点曲げ試験に おいて大きなたわみ異方性が報告されている(Du et al., 2018).

図 8 に積層パネルおよび中間材単体のたわみ異方性と $\theta$ との関係を示す。ここでは台形模様方向と平行な 2 辺 を固定した時のたわみ量を $\delta_{\mathrm{P}}$, 台形模様方向と垂直な 2 辺を固定した時のたわみ量を $\delta_{\mathrm{N}}$ し, 両者の比 $\left(\delta_{\mathrm{N}} / \delta_{\mathrm{P}}\right)$ で異方性を評価した．数值が 1 から乘離するほど異方性が大きいことを示す. 図 $8(\mathrm{a})$ より積層パネルのたわみ異 方性が中間材単体のそれより極端に小さいことがわかる．このことは中間材単体で使用した場合と比較して積層 パネルとして使用した場合にたわみ異方性が大きく改善されることを示唆している.また図 8(b)に図 8(a) の破線 で囲った $\mathrm{A}$ 範囲の拡大図を示寸. 積層パネルのたわみ異方性は $\theta_{\mathrm{md}}\left(=27.1^{\circ}\right)$ 付近の角度において 1 に近く, この角 度付近で最小のたわみを実現すると共に，かつ異方性も解消されることが明らかとなった。
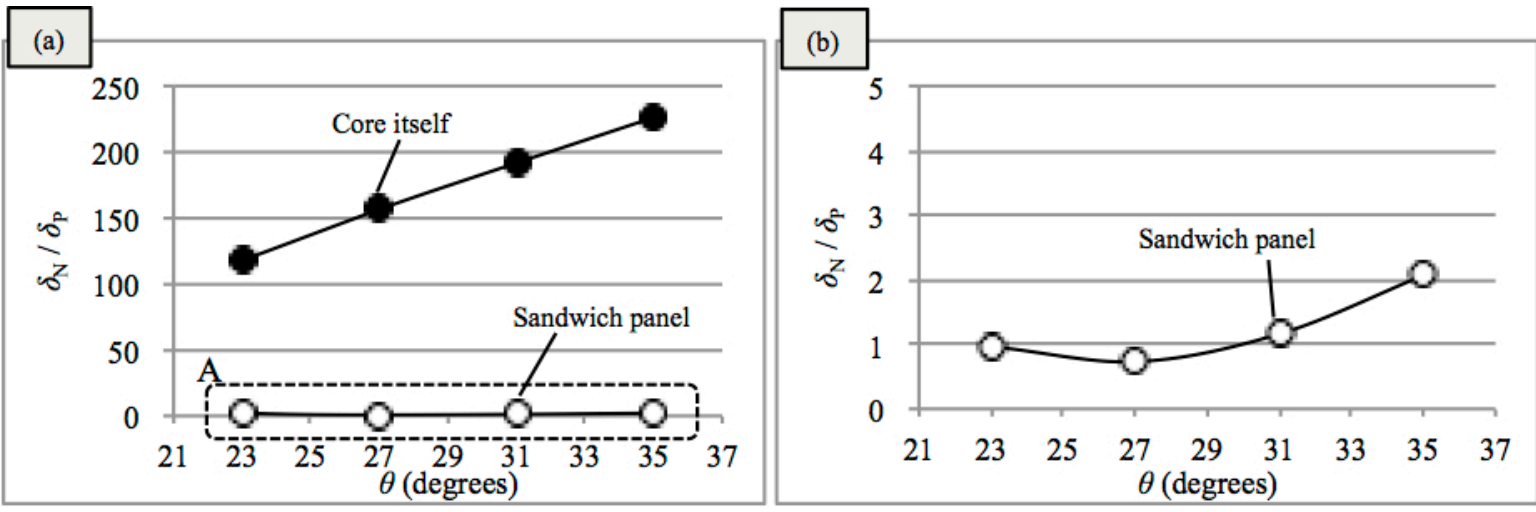

Fig. 8 Comparison of the anisotropy of deflection. (b) is the magnified view of A in (a).

\section{4. 考 察}

\section{$4 \cdot 1$ たわみ量が極小となる角度の発現理由について}

3.2 節においてたわみ量が $\theta$ にっって大きく変化し，たわみ量が極小となる角度 $\theta_{\mathrm{md}}$ が存在した．この発現理由 について考察する.はじめに中間材側壁傾斜部の板厚に式(4)の制約を課さず, 板厚一定とした解析モデルについ て解析を行い，さらに接合層と平板とが接合されていない解析モデルを導入する．これらの解析結果の值より， 側壁傾斜部の板厚，接合の有無や上下面板といった個々の要因がたわみ量に及ぼす影響について調查した.

Model(1):3 章で用いた解析モデル

Model(2):Model(1)から中間材の板厚を一定 $\left[t_{0}\right]$ と変更した解析モデル

Model(3):Model(2から接合層と平板との接触の定義を変更した解析モデル

Model(4):Model(3)から下平板と接合層を取り除いた解析モデル

図 9 に Model(2)の定厚中間材の傾斜部のプロファイルを模式的に示寸. 図中の実線が定厚中間材のプロファイ ルであり, 破線は比較のための Model11のそれである. Model(3)では平板が接合層との接触面上を自由に相対移動 できるように設定を変更した，すなわち平板と中間材とが接合されていない. Model(4)は上記，定厚中間材単体 の状態である．これらの解析結果より $\theta$ の変化に伴う以下の影響を把握することができる.

(A) Model11) - Model(2): 中間材側壁傾斜部の板厚変化の影響

(B) Model(2) - Model(3):接合層界面での接合の有無の影響

(C) Model(3) - Model(4): 上下面板および接合層の有無の影響

図 10 にModel(1) と Model(4)のたわみ量の $\theta$ に対する変化を示す.また上記 $(\mathrm{A}) \sim(\mathrm{C})$ のたわみ量の差の $\theta$ に対す る変化を示す．いずれも 3.2 節と同様に, Moldel(1)の $\theta=27^{\circ}$ のたわみ量 $(13.2 \mu \mathrm{m})$ で正規化している. Model(1)の $\theta$ に対するたわみ量の変化に対し，(4)のたわみ量の変化と，（B）のたわみ量の差の変化が大きい，一方，(A) と (C) の $\theta$ に対するたわみ量の差の変化が小さい, 以上より, 本研究で取り扱った積層パネルのたわみ量には, 定厚中 
間材単体のたわみ特性と，接合層界面での接合の有無の影響が大きいと考えられたそそこでこれらに関して重回 帰分析を行なった．以降，接合層界面での接合の有無の影響を「接合効果」と称する.

目的変数は Model(1)のたわみ量 $(y)$, 説明変数は定厚中間材単体 (Model(4))のたわみ量 $\left(x_{1}\right)$ ，および接合効果 $[(\mathrm{B})]\left(x_{2}\right)$ とし, 目的変数および説明変数全てを標準変量に変換した上で重回帰分析を行なった. 分析は $\theta=23 \sim$ $35^{\circ}$ の各角度に対応する $\left(y, x_{1}, x_{2}\right)$ の 7 組のデータについて行なった. その結果, $x_{1}$ および $x_{2}$ に対する標準偏回帰係 数はそれぞれ $7.01 ，-7.07$ と算出された. 重相関係数は 1.00 と算出され, 重回帰式は分散分析により危険率 $1 \%$ 有意となった. また，各標準偏回帰係数は $\mathrm{t}$ 検定により危険率 $1 \%$ ぞそれぞれ有意となった. 偏回帰係数の值の正 負の状況から，中間材単体のたわみ量が接合効果によって抑制された結果として， $\theta_{\mathrm{md}}$ が発現したことが明らか となった。

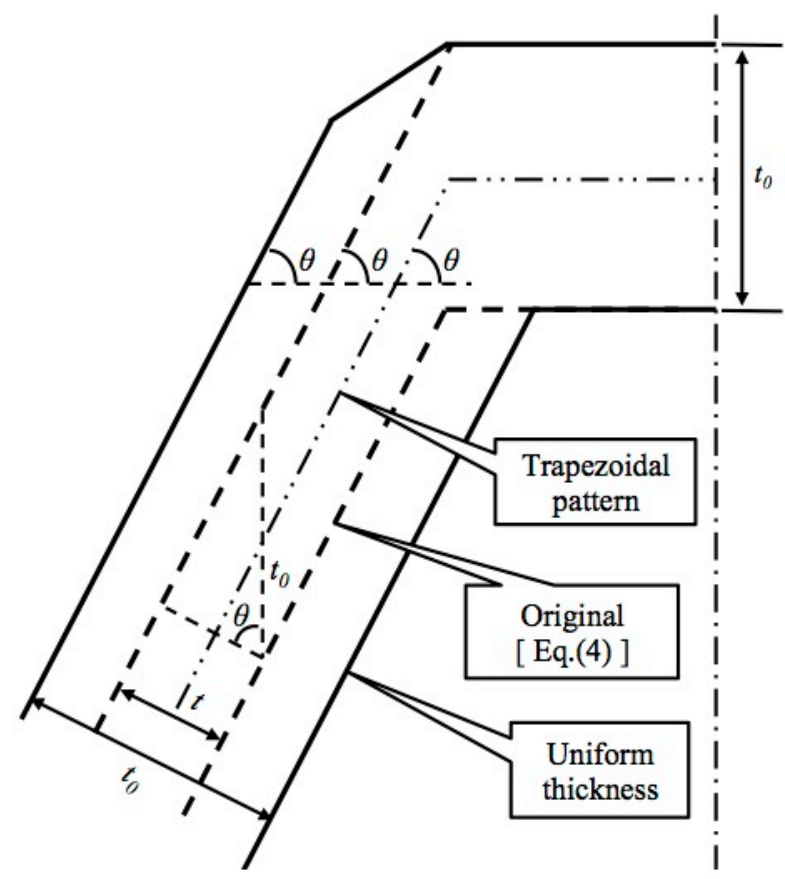

Fig. 9 Schematic diagram of the cross section of the uniform-thickness core.

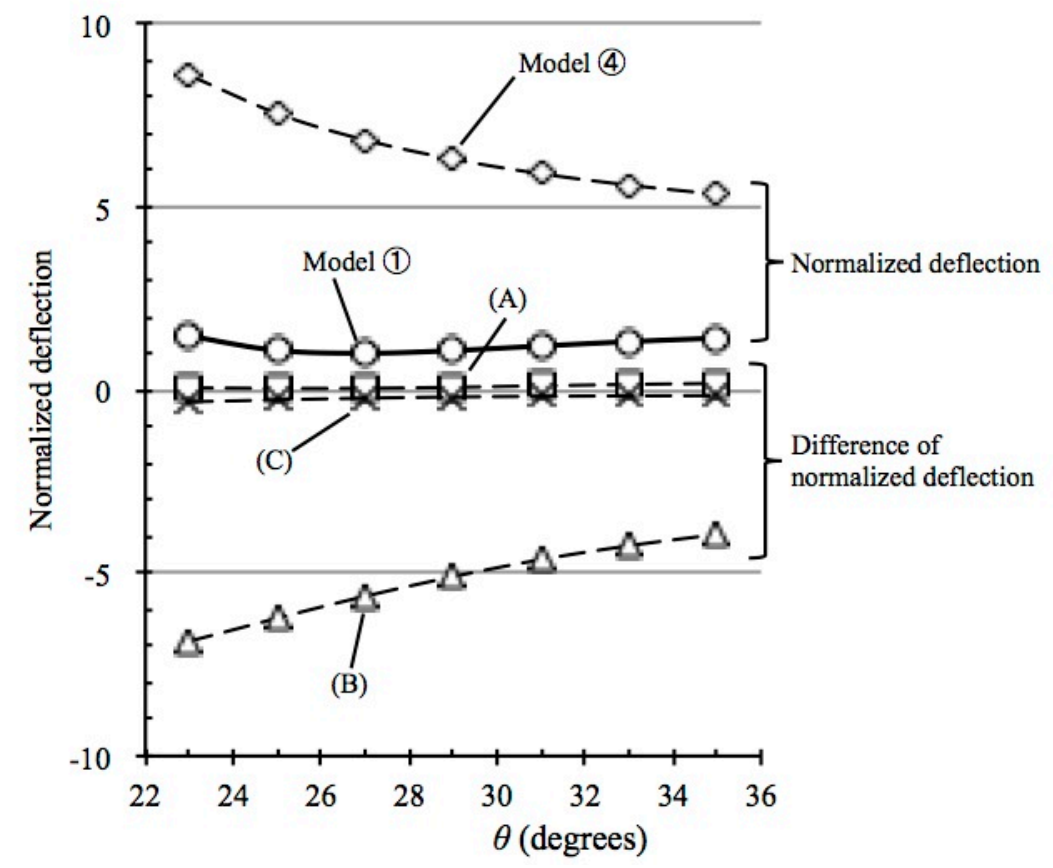

Fig. 10Normalized deflection for Models(1) and (4), and the difference of the normalized deflection for (A) to (C). 


\section{$4 \cdot 2$ 接合効果について}

前節で接合層界面での接合の有無により生じるたわみ量の差を「接合効果」と呼称し，これが積層パネルのた わみ量に大いに影響することを記述した，以下にこの理由について考察する．接合層界面が接合されていない解 析モデル(Model(3))では, 平板や中間材が外力によりたわみ, 内部に引張応力や圧縮応力が発生する．これらの 内力と外力とが釣り合う変形量としてたわみ量が決まる.この時，平板と中間材とは接合されていないので両者 の接触位置は元の場所から相対的に移動する，一方，接合層界面が接合されている解析モデル(Model(2))では, 平板と中間材とが接合されているため接触位置はほとんど移動せず，平板や中間材にせん断応力が発生する．こ のせん断応力が内力に加わるため，同じ值の外力に対して接合層界面が接合されている解析モデルのたわみ量が 接合されていないそれよりも小さくなった.

図 11 に接合層界面が接合されていない解析モデル(Model(3)）と接合されているそれ(Model(2))のたわみと外力 の関係を模式的に示寸. 外力 $F_{1}$ により Model(3)に生じるたわみ量を $\delta_{31}$, Model(2)に生じるそれを $\delta_{21}$ とする. 次に Model(2)のたわみ量を $\delta_{31}$ と等しくするのに必要な外力を $F_{2}$ とすると, Model(2)では Model(3) と等しいたわみ量と なった際， $F_{2}-F_{1}$ に相当する外力がせん断応力による力と釣り合うこととなる. 即ち「接合効果」は $\delta_{31}-\delta_{21}$ で 表され，「たわみ」から「せん断応力」への内力分配による「たわみ」の減少であると考えられる.

ここで接合層のヤング率が変化すれば接合層が平板と中間材に伝達するせん断応力の大きさも変化し，これに より接合効果も変化すると考えられる，そこで接合層のヤング率をこれまで用いた值 $(2.7 \mathrm{GPa})$ より $1.6 \mathrm{GPa}$ 小さ

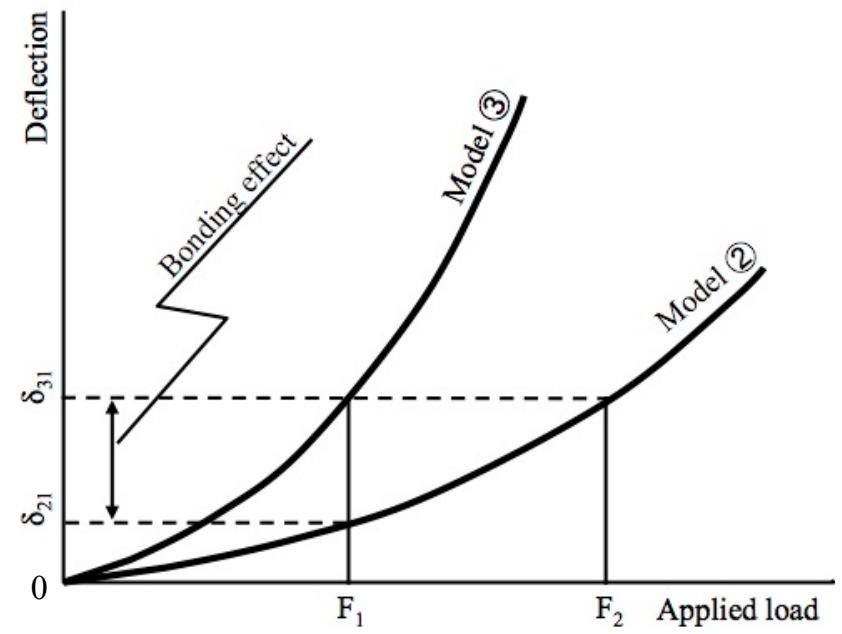

Fig. 11 Illustration of the bonding effect.

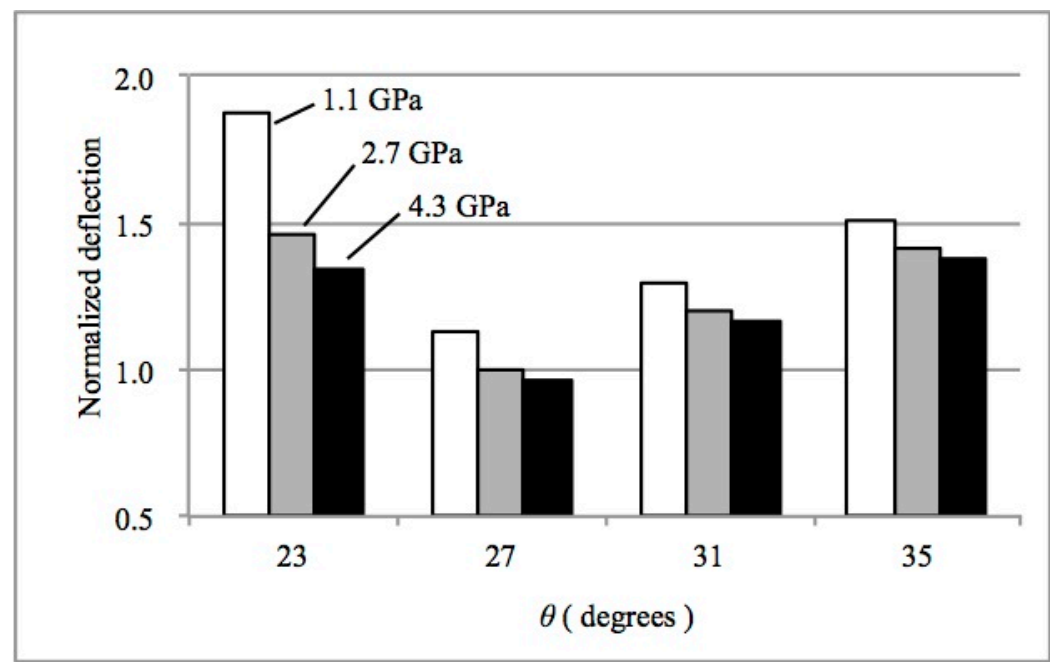

Fig.12 Effect of Young's modulus of bonding layer on the deflection of sandwich panel 
くした場合 (1.1 GPa) と, 逆に $1.6 \mathrm{GPa}$ 大きくした場合 (4.3 GP) について, $\theta=23 \sim 35^{\circ}$ の範囲において Model(1)を 用いた解析を行った．図 12 に積層パネルのたわみ量を示寸. 図よりいずれの きいほどたわみ量が小さく, 接合効果が高いことがわかる. また $\theta=23^{\circ}$ の時に, 接合層のヤング率が $1.1 \mathrm{GPa}$ の 場合と $2.7 \mathrm{GPa}$ の場合とでたわみ量の差異が大きく，暲小さい場合ほど接合効果が高いことがわかる.

\section{5. 結 言}

台形断面の波型中間材を有する積層パネルについて, 幾何学的制約や加工プロセスを考慮した解析モデルを作 成し，有限要素法により中間材の側壁傾斜角度がパネルのたわみ量に及ぼす影響について調查をした．本研究で 得られた知見を以下に示す.

（1）幅 $200 \mathrm{~mm}$ 正方, 高さ $13.6 \mathrm{~mm}$ の積層パネルの四辺を固定し, パネル上平板表面に均等分布荷重 $(16.4 \mathrm{kN}$ $/ \mathrm{m}^{2}$ ) を負荷した際のたわみを算出したところ, たわみ量は中間材の側壁傾斜角度によって变化した. 積層パネル 中央における最大たわみ量は傾斜角度がおよそ $27^{\circ}$ の時極小となり, その值は $13.2 \mu \mathrm{m}$ であった.

（2）中間材の波板構造に起因して生じるたわみ異方性(積層パネルの相対する 2 辺を固定して負荷した際の, 選択する 2 辺の違いによるたわみ量の差) は上下平板を中間材と接合して積層パネルとすることにより大きく改 善され，特にたわみが極小となる側壁傾斜角度付近でほとんど現れなくなることを明らかにした．

（３）４つの解析モデルを作成し, 中間材単体のたわみ特性に加え, 中間材側壁傾斜部の板厚変化, 接合層界 面での接合の有無, および上下平板と接合層の有無が積層パネルのたわみ量に及ぼす影響を調査した. その結果, 中間材単体のたわ久特性と, これに抑制的に作用する接合の有無の影響とのバランスによりたわみが最小となる 側壁傾斜角度が発現することを明らかにした。

（4）（３）の接合の有無が積層パネルのたわみ量に及ぼす影響は, 接合により平板や中間材にせん断応力が発 生寸ることによる分のたわみ量の減少と考えられ，本研究でこれを「接合効果」と呼称した．実際に接合層のヤ ング率を変化させた解析を実施したところ, 接合層のヤング率が低下寸るほどたわみ量は増加し, 特にこの傾向 は中間材側壁傾斜角度が低い領域で顕著であった。

\section{文献}

Chen, A. and Davalos, J. F., A solution including skin effect for stiffness and stress field of sandwich honeycomb core, International Journal of Solids and Structures, Vol.42 (2005), pp.2711-2739.

Cheon, Y.-J. and Kim, H.-G., An equivalent plate model for corrugated-core sandwich panels, Journal of Mechanical Science and Technology, Vol.29 (2015), pp.1217-1223.

Du, B., Chen, L., Tan, J., Zhou, H., Zhao, Y., Wu, W., Li, W., Fang, D. and Chen, L., Fabrication and bending behavior of thermoplastic composite curved corrugated sandwich beam with interface enhancement, International Journal of Mechanical Science, Vol.149 (2018), pp.101-111.

Feng, L.-J., Xiong, J., Yang, L.-H., Yu, G.-C., Yang, W. and Wu, L.-Z., Shear and bending performance of new type enhanced lattice truss structures, International Journal of Mechanical Science, Vol.134 (2017), pp.589-598.

Goto, A., Nihei, H., Zhao, P. and Anami, T., Aluminum sheet material technology supporting the weight reduction of a car body, International Journal of Automotive Engineering, Vol.2 (2011), pp.81-86.

後藤明, 西山公人, 積層パネル, 特許第 6326018 号 (2018).

後藤明, 西山公人, 積層パネル, 特許第 6326019 号 (2018).

土木学会構造工学委員会編, 構造力学公式集 (2003), pp.313-376.

小林秀敏, 臺丸谷政志, 奥戸行一郎, 溶接接合ハニカムパネルの弾塑性曲げ変形, 日本機会学会論文集 A 編, Vol.60 (1994), pp.1011-1016.

野口元，ハニカムの製法と用途，日本金属学会報, Vol.24 (1985), pp.471479.

高橋昌也，等方的なシェル構造の補剛模様の開発，日本機会学会論文集 A 編, Vol.77 (2011), pp.1411-1416.

高橋昌也, 松田紘一, 橋本一真, スマートシートとスマートコアパネルの曲げ岡性, 日本機会学会論文集 A 編, Vol.79 (2013), pp.209-213.

Wilbert, A., Jang, W.-Y., Kyriakides, S. and Floccari, J. F., Buckling and progressive crushing of laterally loaded honeycomb, International Journal of Solids and Structures, Vol.48 (2011), pp.803-816. 
Wu, Q., Gao, Y., Wei, X., Mousanezhad, D. Ma, L., Vaziri, A. and Jian, X., Mechanical properties and failure mechanisms of sandwich panels with ultra-lightweight three-dimensional hierarchical lattice cores, International Journal of Solids and Structures, Vol.132-133 (2018), pp.171-187.

Xia, Y., Friswell, M. I. and Saavedra Flores, E. I., Equivalent models of corrugated panels, International Journal of Solid and Structures, Vol.49 (2012), pp.1453-1462.

Zhang, L., Chen, Y., He, R., Bai, X., Zhang, K., Ai, S., Yang, Y. and Fang, D., Bending behavior of lightweight C/SiC pyramidal lattice core sandwich panels, International Journal of Mechanical Science, Vol.171 (2020), 105409, 9 pages.

\section{References}

Chen, A. and Davalos, J. F., A solution including skin effect for stiffness and stress field of sandwich honeycomb core, International Journal of Solids and Structures, Vol.42 (2005), pp.2711-2739.

Cheon, Y.-J. and Kim, H.-G., An equivalent plate model for corrugated-core sandwich panels, Journal of Mechanical Science and Technology, Vol.29 (2015), pp.1217-1223.

Du, B., Chen, L., Tan, J., Zhou, H., Zhao, Y., Wu, W., Li, W., Fang, D. and Chen, L., Fabrication and bending behavior of thermoplastic composite curved corrugated sandwich beam with interface enhancement, International Journal of Mechanical Science, Vol.149 (2018), pp.101-111.

Feng, L.-J., Xiong, J., Yang, L.-H., Yu, G.-C., Yang, W. and Wu, L.-Z., Shear and bending performance of new type enhanced lattice truss structures, International Journal of Mechanical Science, Vol.134 (2017), pp.589-598.

Goto, A., Nihei, H., Zhao, P. and Anami, T., Aluminum sheet material technology supporting the weight reduction of a car body, International Journal of Automotive Engineering, Vol.2 (2011), pp.81-86.

Goto, A., Nishiyama, K., Sandwich panel, Japanese patent P6326018 (2018).

Goto, A., Nishiyama, K., Sandwich panel, Japanese patent P6326019 (2018).

Japan Society of Civil Engineers, Committee on Structural Engineering ed., The Structural Mechanics Handbook (2003), pp.313-376, Japan Society of Civil Engineers (in Japanese).

Kobayashi, H., Daimaruya, M., Okuto, K., Elasto-plastic bending deformation of welded Honeycomb sandwich panel, Transactions of the JSME, Ser.A, Vol.60 (1994), pp.1011-1016 (in Japanese).

Noguchi, H., Production method and application of honeycomb material, Bulletin of the Japan Institute of Metals, Vol.24 (1985), pp.471-479.

Takahashi, M., Development of isotropic patterned shell structures with high stiffness, Transactions of the JSME, Ser.A, Vol.77 (2011), pp.1411-1416 (in Japanese).

Takahashi, M., Matsuda, K. and Hashimoto, K., Bending stiffness of the SMART SHEET and SMART CORE Panel, Transactions of the JSME, Ser.A, Vol.79 (2013), pp.209-213 (in Japanese).

Wilbert, A., Jang, W.-Y., Kyriakides, S. and Floccari, J. F., Buckling and progressive crushing of laterally loaded honeycomb, International Journal of Solids and Structures, Vol.48 (2011), pp.803-816.

Wu, Q., Gao, Y., Wei, X., Mousanezhad, D. Ma, L., Vaziri, A. and Jian, X., Mechanical properties and failure mechanisms of sandwich panels with ultra-lightweight three-dimensional hierarchical lattice cores, International Journal of Solids and Structures, Vol.132-133 (2018), pp.171-187.

Xia, Y., Friswell, M. I. and Saavedra Flores, E. I., Equivalent models of corrugated panels, International Journal of Solid and Structures, Vol.49 (2012), pp.1453-1462.

Zhang, L., Chen, Y., He, R., Bai, X., Zhang, K., Ai, S., Yang, Y. and Fang, D., Bending behavior of lightweight C/SiC pyramidal lattice core sandwich panels, International Journal of Mechanical Science, Vol.171 (2020), 105409, 9 pages. 